\title{
Da normatividade à subjetividade: nuances do agir- prescritivo educacional na EaD
}

\author{
De la normatividad a subjetividad: detalles del actuar- \\ prescriptivo educacional en EaD
}

\section{From normativity to subjectivity: nuances of educational prescriptive-doing in Distance Education.}

\author{
Kleber Ferreira da Silva ${ }^{1}$
}

\begin{abstract}
RESUMO: O artigo proposto tem como objetivo apresentar uma análise que desvela a forma como o agir-prescritivo é configurado no mais recente documento oficial que normatiza a Educação a Distância no Brasil. Assim, ancorando-se no modelo de análise textual do Interacionismo Sociodiscursivo (ISD), apresenta-se uma análise voltada para a apreensão do contexto sociointeracional em que o documento emana e de alguns mecanismos linguístico-discursivos que proporcionam a compreensão do agir educacional instrumentalizado pelo Decreto no 9.057/2017. Os resultados revelam um agir-prescritivo em que o protagonismo é assumido por instâncias não-humanas, marcado pelo apagamento das instâncias enunciativas e predominância do discurso teórico.
\end{abstract}

PALAVRAS-CHAVE: Prescrição. EaD. Agir. Trabalho. Interacionismo sociodiscursivo.

RESUMEN: El artículo propuesto tiene como objetivo presentar un análisis que devela la manera como el actuar -prescriptivo es configurado en el documento oficial más reciente que rige para la Educación a distancia en Brasil. Así, anclados en el modelo de análisis textual del Interaccionismo Sociodiscursivo (ISD), presentamos un análisis que observa la aprehensión del contexto sociointeraccional en que el documento emana y de algunos mecanismos lingüísticos discursivos que proporcionan la comprensión del actuar educacional instrumentalizado por el Decreto no 9.057/2017. Los resultados revelan un actuar-prescriptivo en que el protagonismo es asumido por instancias que no son humanas, marcado por el apagamiento de las instancias enunciativas y la presencia del discurso teórico.

\footnotetext{
${ }^{1}$ Doutorando em Estudos da Linguagem da Universidade Estadual de Londrina (UEL); Mestre em Linguística e Transculturalidade pela Universidade Federal da Grande Dourados (UFGD). Contato: klebersilvams@gmail.com
} 
PALABRAS CLAVE: Actuar. Trabajo. Prescripción. EaD. Interaccionismo Sociodiscursivo.

ABSTRACT: The proposed paper aims at presenting an analysis that reveals the way in which prescriptive-doing is figured in the latest official documents that govern Distance Education in Brazil. Based in the Socio-discursive Interactionism's (SDI) model of textual analysis, it is presented an analysis that focuses on the apprehension of the sociointeractional context that emerges from the document, and the linguistic-discursive mechanisms that enable the comprehension of the educational doing as instrumentalized by the Decree no 9.057/2017. The results revealed the establishment of a prescriptivedoing in which the central role is played by non-human instances, characterized by the obliteration of enunciative instances and the predominance of theoretical discourse.

KEYWORDS: Prescription. Distance Education. Doing. Work. Socio-discursive interactionism.

\section{Introdução}

A Educação a Distância tem se apresentado como uma tendência expansionista no tocante ao ensino-aprendizagem no Brasil. É sabido, conforme dados oficiais mais recentes (INSTITUTO NACIONAL DE ESTUDOS E PESQUISAS EDUCACIONAIS ANÍSIO TEIXEIRA, 2017), que quase um milhão e meio dos alunos do ensino superior, no Brasil, matricularam-se em cursos da modalidade de Educação a Distância (doravente, EaD).

Os órgãos governamentais, apesar de oficializarem instituições de EaD no início do século XX (ZAMLUTTI, 2006), efetivamente atentaram-se à legalização e regulamentação dos múltiplos vieses dessa antiga demanda educacional, na década de 90, com a aprovação da Lei de Diretrizes e Bases da Educação Nacional (LDB) 9.394/1996 (BRASIL, 1996), regulamentada, à época, pelo Decreto 2.494/1998 (BRASIL, 1998), posteriormente, pelo Decreto 5.622/2005 (BRASIL, 2005) e atualmente pelo Decreto 9.057 de 25 de maio de 2017 (BRASIL, 2017).

É preciso salientar que, no Brasil, a EaD foi profundamente otimizada pela difusão do acesso à internet no final do século XX e passou, conforme (GOMES, 2013, p. 13), pela "era do correio, do rádio e da televisão", vivendo hoje a era da internet. Essa expansão tecnológica cada vez mais ubíqua fomentou e 
continua a fomentar inúmeras reflexões a respeito dos paradigmas de ensinoaprendizagem que ensejam o trabalho do professor e seus instrumentos de ação.

Nesse percurso, do ponto de vista institucional, o ensino a distância delineia-se no cenário nacional legalmente pautado, viabilizando diversos programas e sistemas de ensino públicos, em andamento e amplamente propagados: Programa Nacional de Acesso ao Ensino Técnico e Emprego (Pronatec), Universidade Aberta do Brasil (UAB), Programa Nacional de Formação Continuada em Tecnologia Educacional (ProInfo Integrado), por exemplo.

Contudo, do ponto de vista praxiológico, focado na ação dos profissionais educadores em sala de aulas ou laboratórios multimidiáticos, muitos caminhos estão sendo percorridos e assimilados com vistas à construção de uma expertise que agregue tecnologia e metodologia em prol do desenvolvimento humano de alunos (e por que não de professores, equipes pedagógicas e gestoras da educação?).

Insta que nos debruçemos sobre esse texto prescritivo contemporâneo com o propósito de entender a configuração do agir-prescritivo e quais atores podem emanar (se emanam) desse documento regulamentador da EaD.

Com esse intuito, uma vez apresentada a relevância de analisar o Decreto 9.057 de 25 de maio de 2017, apresentamos os fundamentos teóricos que ancoram a análise, a metodologia de análise, os resultados e as considerações depreendidos a partir da análise proposta sobre o agir no trabalho educacional na EaD.

\section{Pressupostos Teóricos}

\section{A organização temática e a apreensão dos actantes na ação de linguagem: aspectos conceituais e delimitadores do texto prescritivo}

A perspectiva teórico-metodológica que norteia as reflexões propostas neste artigo se assenta na relação entre linguagem e trabalho denominada linguagem sobre o trabalho (NOURODINE, 2002) que, sistematicamente, 
articula-se ao estudo analítico das prescrições descendentes (DANIELLOU, 2002 apud BUENO; TRAVA, 2016).

No escopo do Interacionismo Sociodiscursivo (ISD), o agir humano efetivase por meio de precrições ou prefigurações que são materializadas por textos precedentes ou anteriores à situação de trabalho stricto sensu. Essas prefigurações podem ser prefiguração genérica, materializada em textos provenientes do próprio actante ou outras instâncias, em se tratando do agir fora das restrições impostas pelo trabalho, numa situação "externa" (linguagem sobre o trabalho) ou prefiguração específica, quando se trata de textos que reportam ao agir em situação de trabalho (linguagem no/como trabalho). Assim, classificam-se em:

a) os que provêm de instâncias externas e que indicam, de forma implícita ou explícita, as tarefas que devem ser realizadas no quadro dessa profissão, tais como os textos prescritivos do trabalho educacional, como as leis sobre ensino, os documentos do Ministério da Educação (PCNs) ou das Secretarias da Educação e das divisões regionais, os projetos das escolas, os livros e materiais didáticos, os textos sobre formação de professores etc. b) os textos que os trabalhadores produzem sobre o seu trabalho, antes de uma determinada tarefa, os textos planificadores ou auto-prescritivos, como plano de aulas, planejamento de curso ou qualquer texto produzido por indução do pesquisador sobre o trabalho a ser realizado; ou durante a tarefa, como nas aulas, na correção de provas, em reuniões etc. (MACHADO et al., 2009, p. 91, grifo do autor).

Nesse sentido, partimos dos textos que "prescrevem, planejam, avaliam e interpretam as ações desenvolvidas na situação de trabalho" e não no interior de uma situação de trabalho stricto sensu, conforme (BRONCKART; MACHADO, 2004, p. 136).

Ao elegermos o texto prescritivo como objeto de análise, é importante considerar a noção de prescrição que o enseja. Assim, segundo o dicionário Houaiss, em duas das acepções resgistradas, o termo corresponderia à noção de "norma, preceito, regra" ou "ordem, determinação".

Destarte, sob a rubrica jurídica no sistema público, em se tratando de um ato normativo Di Pietro (2011, p. 225) assevera que o ato normativo (genérico) subordina hierarquicamente 0 ato administrativo (específico/individual). 
Entretanto, no que diz respeito à noção mais holística sobre a prescrição no trabalho, é preciso assumir "a prescrição como algo que não vem sempre de uma autoridade, nem sempre é um enunciado explícito ou intencional" (BUENO; TRAVA, 2016, p. 193).

A remissão a esses aspectos de normatividade do texto prescritivo se faz indispensável na medida em que o gênero textual analisado (BRASIL, 2017) emerge do sistema educacional público brasileiro (sistema de ensino) o qual tem natureza deliberativo-prescritiva sobre os sistemas didáticos (CHEVELLARD, 1991) intrinsecamente a ele vinculados.

\section{0 contexto sociosubjetivo}

Assim sendo, num primeiro plano, segundo Bronckart (2009, p. 93-94), todo texto resulta de um ato (comportamento verbal concreto) realizado em um contexto "físico"definido por quatro parâmetros precisos: 1) o lugar de produção (lugar físico); 2) o momento de produção (extensão do tempo/duração da produção); 3) o emissor - ou produtor/locutor - (a pessoa, ou máquina que produz fisicamente o texto oral ou escrito 4 ) o receptor ( $\mathrm{a}[\mathrm{s}]$ pessoa [s] que pode $[\mathrm{m}]$ perceber/ receber concretamente o texto, sendo um o co-produtor (texto oral) ou interlocutor (texto escrito). Num segundo plano, a produção de todo o texto inscreve-se numa formação social e, mais especificamente, no quadro de uma forma de interação comunicativa que implica o mundo social (normas, valores, regras, etc.) e o mundo subjetivo (imagem que o agente faz de si ao agir): contexto sociosubjetivo. Esse contexto (sociosubjetivo) decompõese em quatro parâmetros principais: 1) o lugar social (formação social, instituição, em que modo de interação o texto é produzido: escola, família, mídia, interação informal, comercial, etc.); 2) a posição social do emissor (que the concede seu estatuto de enunciador: qual é o seu papel social na interação? professor, pai, cliente, superior hierárquico, etc.) 3) a posição social do receptor (que the assegura o estatuto de destinatário): qual é o papel social atribuído ao receptor do texto: papel de aluno, de criança, de colega, de subordinado, de amigo, etc.? 
4) o objetivo (ou os objetivos) da interação: qual é (ou quais são) os efeitos, do ponto de vista do enunciador, que o texto pode produzir para (no) destinatário?

\section{A infraestrutura global do texto}

Segundo Bronckart (2013, p. 94), no processo de adaptação, os textos se transmitem e são reproduzidos ou reinvestidos no tempo e no espaço, de modo que os signos que eles comportam são afetados por novos valores significantes, conferindo a eles um estatuto de "meio intermediário", isto é, um meio de trânsito entre representações individuais e representações coletivas, de onde se emana a construção e reconstrução de valores significantes.

As formas de organização textual, denominadas de arquitetura textual, de acordo com a proposta de Bronckart (2013, p. 96), podem ser decompostas em quatro níveis: 1) texto - unidade comunicativa/plano textual global: características (externas) articuladas à funcionalidade praxeológica e sociocultural do gênero; 2) tipos de discurso: segmentos de textos reconhecíveis pela configuração de unidades linguística que eles comportam. Estas, por seu turno, reveladoras do posicionamento enunciativo no "mundo" evocado (disjunto ou conjunto) ao "mundo" da interação verbal. Esses tipos de discurso podem ser classificados como discurso interativo, discurso teórico, relato interativo, narração; 3) textualização: mecanismos que contribuem para a o estabelecimento da coerência temática dos textos; 4) responsabilidade enunciativa: mecanismos que compõe as vozes e modalizações postas na textualidade, contribuindo para a coerência interativa.

Em outra publicação, Bronckart (2009, p. 119-135), apresenta a arquitetura interna dos textos como: 1) a infraestrutura textual: composta por três camadas superpostas (plano textual global, tipos de discurso, sequências); 2) os mecanismos de textualização: realizados por organizadores textuais, articuladores hierárquicos, lógicos e/ou temporais; 3) os mecanismos enunciativos: formas pronominais, sintagma nominal, frases ou segmentos de frase: vozes e modalizações que evidenciam o posicionamento enunciativo. 


\section{O plano geral:}

O plano geral refere-se à organização de conjunto do conteúdo temático; mostra-se visível no processo de leitura e pode ser codificado em um resumo (BRONCKART, 2009, p. 120). Nessa perspectiva, o autor idealiza que "[...] o plano geral de um texto é descrito, não com base em uma análise detalhada dos tipos de discurso e das diversas formas de planificação que ele combina, mas na forma de um resumo do conteúdo temático [...]." (BRONCKART, 2009, p. 248).

Salientamos que a apreensão do plano global requer a assimilação da ação de linguagem que, segundo Bronckart (2009, p. 99), como qualquer ação humana, define-se em um primeiro nível sociológico (relacionado ao grupo, às avaliações sociais e imputada a um organismo humano em particular) e num nível psicológico (relacionado com o conhecimento disponível em um organismo ativo sobre as diferentes facetas da sua própria responsabilidade de intervenção verbal. Nesse segundo nível, ressalta-se que a noção de linguagem reúne e integra os parâmetros do contexto de produção e do conteúdo temático, tais como determinado agente os mobiliza, em dada intervenção verbal.

Nesse sentido, depreendemos que formular o plano geral (ou plano textual global) requer voltar-se para a "noção de linguagem" a fim de descrever sumariamente os movimentos tópicos ou a concatenação temática representada e externada por um agente numa ação de linguagem.

\section{As formas de agir e suas apreensões}

Conforme Bronckart e Machado (2004), a apreensão do plano global pode ser ampliada quando nos atentamos para a menção aos tipos do agir acionados que podem ser: a) o agir prescritivo: quando o núcleo temático é o ato oficial realizado pelo signatário da mensagem; b) o agir-fonte: o trabalho de elaboração/produção do documento; c) o agir-decorrente que se refere à 
utilização posterior dos documentos, elencando, de modo genérico, diversos atos a serem realizados no sistema educacional abordado.

\section{Os tipos de discurso e as marcas enunciativas}

Há, conforme Bronckart (2009, p. 155), quatro mundos discursivos que combinam, por um lado, a oposição entre a ordem do narrar e a ordem do expor e, por outro lado, a implicação e autonomia dos parâmetros da ação de linguagem em curso (agente-produtor, interlocutor eventual e sua situação no espaço-tempo).

Nesse sentido, sob o ângulo das operações psicológicas em que se baseiam, (BRONCKART, 2009, p. 157) apresenta os mundos discursivos e seus tipos psicológicos correspondentes (associados), elencando a correlação: 1) mundo do expor implicado: discurso interativo; 2) mundo do expor autônomo: discurso teórico; 3) mundo do narrar implicado: relato interativo; 4) mundo do narrar autônomo: narração.

Dentre as marcas enunciativas, além dos tempos verbais predominantes, há que se observar a presença de unidades que remetem ou a objetos acessíveis aos interactantes ou ao espaço ou ao tempo de interação: ostensivos, dêiticos espaciais, dêiticos temporais, dentre outros aspectos linguístico-discursivos².

No próximo tópico, apresentamos a metodologia de trabalho que pauta a análise proposta neste artigo.

\section{Metodologia de análise}

A reflexão proposta aqui tem como viés três questões de pesquisa que conduzem o olhar investigativo sobre o agir-prescritivo na EaD:Como o agirreferente é representado e quais agentes o caracterizam nas definições de EaD presentes no Decreto 9.057 de 25 de maio de 2017 e outros dois textos

\footnotetext{
${ }^{2}$ Para um maior aprofundamento sobre os tipos de discurso e marcas enunciativas, remetemos 0 leitor a Bronckart (2009, p. 155-216).
} 
prescritivos predecessores? Como se configura o contexto de produção e o plano global organizador dos temas abordados no Decreto 9.057/2017? Quais tipos de discursos emergem nos segmentos temáticos que focalizam o agir-referente no Decreto 9057/2017?

A busca de respostas a esses (e outros) questionamentos nos remetem ao modelo de análise textual proposta por Bronckart (1999), enfatizando num primeiro momento aspectos linguístico-discursivos em nível temático e organizacional e, noutro, em nível enunciativo. Para identificar os protagonistas do agir elencados nos segmentos temáticos do Decreto 9.057/2017, como já mencionado, tem como aporte a proposta de análise de Bronckart e Machado (2004) inspirada em Fillmore (1975) que apresenta os seguintes papéis cracterizadores dos sujeitos ou complementos verbais e respectivas funções sintático-semânticas, conforme quadro 1:

Quadro 1 - Classificação do estatuto sintático-semântico dos protagonistas

\begin{tabular}{|c|l|}
\hline $\begin{array}{c}\text { Papel atribuído ao } \\
\text { sujeito ou ao } \\
\text { complemento }\end{array}$ & \multicolumn{1}{c|}{ Característica definidora } \\
\hline Agentivo & O ser animado responsável por um processo dinâmico \\
\hline Instrumental & $\begin{array}{l}\text { A força ou o objeto inanimado que é a causa imediata de um evento } \\
\text { ou que contribui para a realização de um processo dinâmico, que } \\
\text { está, assim, envolvido na ação ou estado identificados pelo verbo }\end{array}$ \\
\hline $\begin{array}{c}\text { Atributivo (ou } \\
\text { Experienciador) }\end{array}$ & $\begin{array}{l}\text { A entidade a quem é atribuída uma determinada sensação ou } \\
\text { determinado estado. O papel do sujeito, nessas orações, é o de um } \\
\text { portador de estado, de um suporte de um estado/condição } \\
\text { expresso pelo verbo }\end{array}$ \\
\hline Objetivo & A entidade que sofre um processo dinâmico \\
\hline Beneficiário & O destinatário animado de um processo dinâmico \\
\hline Factivo & O estado ou o resultado final de uma ação expressa pelo verbo \\
\hline
\end{tabular}

Fonte: Adaptado de Bronckart e Machado (2004).

\section{Processo de análise linguístico-discursiva e apreensões}

O contexto sócio-histórico e interacional do Decreto e os agentes implicados no segmento textual que apresenta o objeto de prescrição (a EaD) 
A EaD figura na legislação brasileira como uma modalidade de ensino, regulamentada pelo Decreto 9.057 de 25 de maio de 2017, ato normativo que revogou aquele publicado em 2005 (BRASIL, 2005). Nessa perspectiva, consideramos importante averiguar a concepção de EaD que tem pautado o Decreto 9.057 de 25 de maio de 2017 e qual o seu avanço conceitual, considerando o percurso semântico que o termo percorreu do final da década de 90 até 2017. Assim sendo, buscamos evidenciar quais são os signos e os agentes que emergem nos segmentos textuais que indicam o objeto ou âmbito de aplicação do texto prescritivo, no caso a $\mathrm{EaD}$, num percurso histórico específico.

Para isso, de modo análogo ao adotado por Abreu Tardelli (2004), porém com a focalização sobre um segmento textual específico, utilizamos a análise proposta por Bronckart e Machado (2004), no que diz respeito à Semiologia do agir, para revelar os protagonistas colocados em evidência nas definições de $\mathrm{EaD}$ apresentadas nos documentos abordados.

A EaD figurou primeiramente na legislação brasileira (BRASIL, 1998), nos seguintes termos:

Art. $1^{0}$ Educação a distância é uma forma de ensino que possibilita a auto-aprendizagem, com a mediação de recursos didáticos sistematicamente organizados, apresentados em diferentes suportes de informação, utilizados isoladamente ou combinados, e veiculados pelos diversos meios de comunicação. (BRASIL, 1998, p. 1)

Quadro 2 - Classificação do estatuto sintático-semântico dos protagonistas

\begin{tabular}{|l|l|l|l|l|}
\hline Protagonista & $\begin{array}{l}\text { Função } \\
\text { sintática }\end{array}$ & $\begin{array}{l}\text { Função } \\
\text { semântica }\end{array}$ & Tipo de frase & Verbo \\
\hline $\begin{array}{l}\text { A educação a a } \\
\text { distância }\end{array}$ & sujeito & Atributivo & Principal ativa & é \\
\cline { 2 - 5 } & sujeito & Instrumental & $\begin{array}{l}\text { Subordinada } \\
\text { ativa }\end{array}$ & possibilita \\
\hline forma de ensino & sujeito & Instrumental & $\begin{array}{l}\text { Subordinada } \\
\text { ativa }\end{array}$ & possibilita \\
\hline auto-aprendizagem & complemento & Factivo & $\begin{array}{l}\text { Subordinada } \\
\text { ativa }\end{array}$ & possibilita \\
\hline
\end{tabular}

Fonte: elaborado pelo autor.

Percebemos aqui o protagonismo assumido pela "EaD", pela "forma de ensino" e pela "auto-aprendizagem", ou seja, por entidades inanimadas que 
agem ou sofrem o processo da ação. Nesse sentido, em um contexto marcado pela popularização do acesso à internet e seus mecanismos propulsores da EaD, ressalta-se primordialmente o "boom" tecnológico e seu potencial processo "mediador" no sistema educacional do país.

Na publicação do ato normativo de 2005, a Educação a Distância é definida in verbis,

Art. $1^{0}$ Para os fins deste Decreto, caracteriza-se a educação a distância como modalidade educacional na qual a mediação didático-pedagógica nos processos de ensino e aprendizagem ocorre com a utilização de meios e tecnologias de informação e comunicação, com estudantes e professores desenvolvendo atividades educativas em lugares ou tempos diversos. (BRASIL, 2005, p. 1).

Quadro 3 - Classificação do estatuto sintático-semântico dos protagonistas

\begin{tabular}{|l|l|l|l|l|}
\hline Protagonista & $\begin{array}{l}\text { Função } \\
\text { sintática }\end{array}$ & $\begin{array}{l}\text { Função } \\
\text { semântica }\end{array}$ & Tipo de frase & Verbo \\
\hline A educação a distância & Sujeito & atributivo & Principal ativa & Caracteriza-se \\
\hline $\begin{array}{l}\text { a mediação didático- } \\
\text { pedagógica }\end{array}$ & sujeito & instrumental & $\begin{array}{l}\text { Subordinada } \\
\text { ativa }\end{array}$ & ocorre \\
\hline $\begin{array}{l}\text { utilização de meios e } \\
\text { tecnologias }\end{array}$ & complemento & instrumental & $\begin{array}{l}\text { Subordinada } \\
\text { ativa }\end{array}$ & ocorre \\
\hline $\begin{array}{l}\text { estudantes } \\
\text { professores }\end{array}$ e & sujeito & agentivo & $\begin{array}{l}\text { Subordinada } \\
\text { ativa }\end{array}$ & desenvolvendo \\
\hline
\end{tabular}

Fonte: elaborado pelo autor.

Essa definição, que emerge de um contexto já permeado pela experiência em $\mathrm{EaD}$, embora em fase germinal, coloca em cena "a mediação didáticopedagógica" agenciada por uso de recursos tecnológicos e pela ação de humanos (embora na condição de agentes e não atores).

No texto prescritivo de 2017, a noção se configura com a seguinte acepção,

Art. $1^{0}$ Para os fins deste Decreto, considera-se educação a distância a modalidade educacional na qual a mediação didático-pedagógica nos processos de ensino e aprendizagem ocorra com a utilização de meios e tecnologias de informação e comunicação, com pessoal qualificado, com políticas de acesso, com acompanhamento e avaliação compatíveis, entre outros, e desenvolva atividades educativas por estudantes e profissionais da educação que estejam em lugares e tempos diversos. (BRASIL, 2017, p. 1). 
Quadro 4 - Classificação do estatuto sintático-semântico dos protagonistas

\begin{tabular}{|l|l|l|l|l|}
\hline Protagonista & $\begin{array}{l}\text { Função } \\
\text { sintática }\end{array}$ & $\begin{array}{l}\text { Função } \\
\text { semântica }\end{array}$ & $\begin{array}{l}\text { Tipo de } \\
\text { frase }\end{array}$ & Verbo \\
\hline A educação a distância & sujeito & atributivo & $\begin{array}{l}\text { Principal } \\
\text { ativa }\end{array}$ & $\begin{array}{l}\text { considera- } \\
\text { se }\end{array}$ \\
\hline mediação didático-pedagógica & sujeito & instrumental & $\begin{array}{l}\text { Subordinada } \\
\text { ativa }\end{array}$ & ocorra \\
\hline $\begin{array}{l}\text { pessoal qualificado, políticas } \\
\text { de acesso, acompanhamento e } \\
\text { avaliação compatíveis }\end{array}$ & complemento & instrumental & $\begin{array}{l}\text { Subordinada } \\
\text { ativa }\end{array}$ & ocorra \\
\hline atividades educativas & complemento & instrumental & $\begin{array}{l}\text { Subordinada } \\
\text { ativa }\end{array}$ & desenvolva \\
\hline $\begin{array}{l}\text { estudantes e profissionais da } \\
\text { educação }\end{array}$ & sujeito & atributivo & $\begin{array}{l}\text { Subordinada } \\
\text { ativa }\end{array}$ & estejam \\
\hline
\end{tabular}

Fonte: elaborado pelo autor.

No documento mais recente, "a mediação didático-pedagógica" figura com outros actantes e instrumentos enumerados na perspectiva de igual importância como "pessoal qualificado", "políticas de acesso", "acompanhamento e avaliação compatíveis" além dos já evocados estudantes e professores ou outros profissionais (talvez, tutores dentre outros), denominados então de "profissionais da educação". Esses últimos, porém, aqui continuam a figurarem como agentes, não dotados de motivos e intenções (BRONCKART; MACHADO, 2004).

Essa representação conceitual denota o caminho percorrido ao longo de quase duas décadas de legalização efetiva e desenvolvimento da EaD, na qual fica claro que a implementação de recursos tecnológicos mais dinâmicos tão aclamada e enfatizada outrora é apenas um dos vieses pelos quais se instrumentaliza e concretiza a EaD no país.

A partir das concepções figurada nos três últimos documentos que regulamentaram a EaD na educação brasileira, nas duas últimas décadas, percebemos um movimento histórico e social representado na linguagem dos documentos oficiais em pauta.

No transcorrer cronológico, notamos que o conceito se reformula e agrega outros agentes em sua composição, sobremaneira, humanos ou ligados à atividade humana. Nesse sentido, percebemos que, desde o final da década de 90 até hoje, o avanço tecnológico e o discurso das instâncias educacionais personalizado em seus atores (pesquisadores, professores, educadores, 
gestores, enfim, experts experientes) exercem, por ora, uma ínfima influência sobre o modo como a EaD é representada oficialmente pelo Estado.

\section{Aspectos globais do texto prescritivo analisado}

O texto analisado normalmente por sua natureza pública tem como suporte as versões digital e impressa, disponibilizadas regularmente pela Imprensa Nacional no Diário Oficial da União (DOU) órgão governamental vinculado à Presidência da República3 ${ }^{3}$. Trata-se de uma versão digital (pdf) disponibilizada pelo sítio da imprensa nacional que também é certificada pelo DOU, edição no 100 , seção 1, p. 3, em versão digital (pdf) no sítio daquela entidade.

No aspecto de formalização estética ou físico-visual, o timbre composto pelo selo da Presidência da República e da Imprensa Nacional, a estruturação típica de atos normativos, dividido em três partes: a) parte preliminar: a epígrafe, a ementa, o preâmbulo e a indicação ou enunciação do objeto); b) parte normativa: o texto ou corpo da lei; c) parte final: as disposições relacionadas às medidas necessárias para implementação da norma, as disposições transitórias e as cláusulas de vigência e de revogação relacionadas ao ato denotam o caráter oficial do documento.

Ademais, podemos elencar ainda articulação do texto prescritivo que se materializa por intermédio de 4 capítulos desprovidos de seções, organizados em vinte e cinco artigos desdobrados em parágrafos ou incisos. Observamos também o "fecho da lei", a assinatura do Presidente da República e referenda por parte do Ministro de Estado (BRASIL, 2018a, p. 93-95).

O texto mobiliza um gênero da ordem de "descrever ações" (DOLZ; NOVERRAZ; SCHNEWVLY, 2004, p. 102), ou seja, um gênero de regulação mútua de comportamentos, consideradas: a sua característica funcional (prescritivo-

\footnotetext{
${ }^{3}$ Conforme informação disponível no sítio do Diário Oficial da União (DOU), após se tornar exclusivamente digital em novembro de 2017, o DOU permite o compartilhamento em redes socias (BRASIL, 2018a).
} 
instrucional), o suporte e os meios de veiculação ao quais se vincula (instituições públicas e demais instâncias relacionadas como a EaD) e os aspectos contextuais relacionados com o emissor e destinatário da publicação oficial, conforme já explicitado nesta seção.

\section{Da análise sobre a infraestrutura global do texto}

\section{Do plano global}

No plano global, identificamos 15 segmentos temáticos dos quais 8 abordam cursos, polos, órgãos/instituições como temas centrais.

Quadro 5 - Concatenação temática no plano global do Decreto 9.057/2017

\begin{tabular}{|l|l|l|}
\hline \multicolumn{2}{|c|}{ Plano-global - ordenação temática } \\
\hline 1 & $\begin{array}{l}\text { Epígrafe, ementa e preâmbulo situando o documento em natureza } \\
\text { jurídica, temporal e temática }\end{array}$ & $\begin{array}{c}\text { Parte } \\
\text { preliminar }\end{array}$ \\
\hline 2 & Definição de EaD: objeto de aplicação do ato normativo & $\begin{array}{l}\text { Art. 10 - Art. } \\
40\end{array}$ \\
\hline 3 & Definição de polo de EaD & Art. 50 \\
\hline 4 & Articulação entre os órgãos e entidades para oferta de EaD & $\begin{array}{l}\text { Art. } 6^{0} \text { - Art. } \\
70\end{array}$ \\
\hline 5 & $\begin{array}{l}\text { Oferta de cursos na educação básica em níveis e modalidades } \\
\text { espećficos }\end{array}$ & $\begin{array}{l}\text { Art. } 8^{0} \text { - Art. } \\
10\end{array}$ \\
\hline 6 & $\begin{array}{l}\text { Ofertas de cursos na educação superior: credenciamento das } \\
\text { instituições de ensino superior }\end{array}$ & $\begin{array}{l}\text { Art. 11 - Art. } \\
14\end{array}$ \\
\hline 7 & $\begin{array}{l}\text { Atividades dos cursos pós graduação lato sensu, criação e extinção de } \\
\text { polos }\end{array}$ & $\begin{array}{l}\text { Art. } 15 \text { - Art. } \\
16\end{array}$ \\
\hline 8 & $\begin{array}{l}\text { Autorização e reconhecimento de cursos superiores na modalidade a } \\
\text { distância }\end{array}$ & Art. 17 \\
\hline 9 & $\begin{array}{l}\text { A oferta de programas de pós-graduação stricto sensu na modalidade a } \\
\text { distância }\end{array}$ & Art. 18 \\
\hline 10 & $\begin{array}{l}\text { O regime de parceria entre a instituição de ensino credenciada para } \\
\text { educação a distância e outras pessoas jurídicas }\end{array}$ & Art. 19 \\
\hline 11 & $\begin{array}{l}\text { Ações de monitoramento, de avaliação e de supervisão de cursos, } \\
\text { polos ou instituições de ensino por órgãos competentes }\end{array}$ & Art. 20 \\
\hline 12 & Dispositivos transitórios sobre autorização, credenciamento, avaliação & $\begin{array}{l}\text { Art. } 21 \text { - Art. } \\
23\end{array}$ \\
\hline 13 & $\begin{array}{l}\text { Revogação de atos predecessores e decreto de vigência do ato } \\
\text { normativo apresentado }\end{array}$ & Art. 24 \\
\hline 14 & $\begin{array}{l}\text { Data/fecho da lei } \\
\text { Ast. 25 }\end{array}$ \\
\hline 15 & $\begin{array}{l}\text { Assinatura e referenda do ato por parte das autoridades implicadas } \\
\text { da lei }\end{array}$ \\
\hline
\end{tabular}

Fonte: elaborado pelo autor 
No tocante à focalização do agir no plano global, na essência ontogênica desse documento, apreendemos um agir-prescritivo (agir-referente) que é denotado: a) a partir do propósito ou do ato regulamentador que o próprio documento instaura (excerto 1); b) com o "ato" oficial realizado pelo signatário que "decreta" por meio do documento (excerto 2); c) na delimitação de sentido do objeto de regulamentação (definição de EaD) admitida (excerto 3).

Os excertos que seguem exemplificam as três nuances que configuram a menção do agir-prescritivo (agir-referente) na compreensão do plano global (BRONCKART; MACHADO, 2004).

\author{
Excerto 1 \\ DECRETO No 9.057, DE 25 DE MAIO DE 2017 \\ Regulamenta o art. 80 da Lei no 9.394, de \\ 20 de dezembro de 1996, que estabelece as \\ diretrizes e bases da educação nacional
}

\title{
Excerto 2
}

O PRESIDENTE DA REPÚBLICA, no uso das atribuições que the confere o art. 84, caput, incisos IV e VI, alínea "a", Da Constituição, e tendo em vista o disposto no art. 80 da Lei no 9.394, de 20 de dezembro de 1996, na Lei no 10.861, de 14 de abril de 2004 e na Lei no 13.005, de 25 de junho de 2014,

\section{DECRETA:}

\section{Excerto 3}

Art. $1^{0}$ Para os fins deste Decreto, considera-se educação a distância a modalidade educacional na qual a mediação didático-pedagógica nos processos de ensino e aprendizagem ocorra com a utilização de meios e tecnologias de informação e comunicação, com pessoal qualificado, com políticas de acesso, com acompanhamento e avaliação compatíveis, entre outros, e desenvolva atividades educativas por estudantes e profissionais da educação que estejam em lugares e tempos diversos (BRASIL, 2017).

Identificamos também um agir-decorrente (agir futuro) representado nas ações a serem efetivadas para implementar legalmente a oferta de cursos na educação básica e na educação superior na modalidade a distância (excertos 4, 5 e 6$)$.

\section{Excerto 4}


Art. 12. As instituições de ensino superior públicas dos sistemas federal, estaduais e distrital ainda não credenciadas para a oferta de cursos superiores na modalidade a distância ficam automaticamente credenciadas, pelo prazo de cinco anos [...]

\section{Excerto 5}

Art. $3^{\circ}$ A criação, a organização, a oferta e o desenvolvimento de cursos a distância observarão a legislação em vigor e as normas específicas expedidas pelo Ministério da Educação.

\section{Excerto 6}

Parágrafo único. Os polos de educação a distância deverão manter infraestrutura física, tecnológica e de pessoal adequada aos projetos pedagógicos ou de desenvolvimento da instituição de ensino e do curso (BRASIL, 2017).

\section{Dos tipos de discurso e das marcas enunciativas}

A partir de critérios socioenunciativos que configuram os mundos dicursivos (BRONCKART, 2009, p. 155), desvelamos dois tipos de discurso (o discurso teórico e o discurso interativo) compondo a planificação do conteúdo temático do documento oficial analisado.

\section{Discurso interativo}

Identificamos predominantemente o discurso interativo, no caso, em sua forma monológica, marcado por um subsistema de tempos verbais composto pelo futuro simples (com valor modal deôntico, excertos 7, 11, 20) ou futuro perifrástico (excertos 6, 8, 12 ao 19, 21) pelo presente (excertos 1, 2, 3) e, em menor proporção, pelo pretérito composto (excertos 4,9 ), denotando o caráter implicado no mundo discursivo do expor:

\section{Excerto 7}

Art. 18. A oferta de programas de pós-graduação stricto sensu na modalidade a distância ficará condicionada à Recomendação da Coordenação de Aperfeiçoamento de Pessoal de Nível Superior - Capes, observadas as diretrizes e os pareceres do Conselho Nacional de Educação 


\section{Excerto 8}

Art. $2^{\circ} \mathrm{A}$ educação básica e a educação superior poderão ser ofertadas na modalidade a distância nos termos deste Decreto, observadas as condições de acessibilidade que devem ser asseguradas nos espaços e meios utilizados.

\section{Excerto 9}

Art. 24. Ficam revogados.

I - o Decreto no 5.622, de 19 de dezembro de 2005; e [...] (BRASIL, 20017).

Aspectos que implicam a instância de enunciação (dêiticos espaciais e temporais) também foram encontrados: a epígrafe (excerto 1), o fecho do decreto e a identificação dos signatários (excerto 10) reportam aos aspectos do mundo ordinário semiotizado no discurso interativo:

\section{Excerto 10}

Brasília, 25 de maio de 2017; $196^{\circ}$ da Independência e $129^{\circ}$ da República.

MICHEL TEMER

JOSÉ MENDONÇA BEZERRA FILHO (BRASIL, 2017).

Acrescentamos ainda a predominância de frases declarativas na construção do texto legislativo (excerto 11) e a presença de verbos auxiliares de modo (poder) assim como de outros auxiliares com valor pragmático do tipo de (querer, dever, ser preciso), imprimindo uma modalização deôntica (excertos 12 ao 19,21$)$ :

\section{Excerto 11}

Art. 70 Os sistemas de ensino, em regime de colaboração, organizarão e manterão abertos ao público os dados e atos referentes a [...]

\section{Excerto 12}

$\S 40$ As escolas de governo do sistema federal credenciadas pelo Ministério da Educação para oferta de cursos de pós-graduação lato sensu poderão ofertar seus cursos nas modalidades presencial e a distância.

\section{Excerto 13}

Art. 20. Os órgãos competentes dos sistemas de ensino poderão, motivadamente, realizar ações de monitoramento, de avaliação de supervisão de cursos, polos ou instituições de ensino, observada a 
legislação em vigor e respeitados os princípios do contraditório e da ampla defesa.

\section{Excerto 14}

$\S 5^{\circ}$ As instituições de ensino poderão optar pelo não arquivamento dos endereços não avaliados, na forma a ser estabelecida em regulamento.

\section{Excerto 15}

Art. 11. As instituições de ensino superior privadas deverão solicitar credenciamento para a oferta de cursos superiores na modalidade a distância ao Ministério da Educação.

\section{Excerto 16}

$\S 5^{\circ}$ As escolas de governo dos sistemas estaduais e distrital deverão solicitar credenciamento ao Ministério da Educação para oferta de cursos de pós-graduação lato sensu na modalidade a distância.

\section{Excerto 17}

Parágrafo único. Na hipótese de que trata o caput, as instituições de ensino_deverão informar o Ministério da Educação quando da oferta de curso superior na modalidade a distância [...]

\section{Excerto 18}

$\S 2^{\circ} \mathrm{A}$ extinção de polo de educação a distância deverá ser informada ao Ministério da Educação após o encerramento de todas as atividades educacionais, assegurados os direitos dos estudantes matriculados e da comunidade acadêmica.

\section{Excerto 19}

Art. 17. Observado o disposto no art. 14 , os pedidos de autorização, de reconhecimento e de renovação de

reconhecimento de cursos superiores na modalidade a distância, ofertados nos limites dos Estados e do Distrito Federal nos quais estejam sediadas as instituições de ensino dos sistemas estaduais e distrital, deverão tramitar nos órgãos competentes [...]

\section{Excerto 20}

$\S 10$ A parceria de que trata o caput deverá ser formalizada em documento próprio, o qual conterá as obrigações das Entidades parceiras $[\ldots]$

\section{Excerto 21}

$\S 2^{\circ} \mathrm{O}$ documento de formalização da parceria de que trata $\circ \S 1^{\circ}$, ao qual deverá ser dada ampla divulgação, deverá ser elaborado em consonância com o Plano de Desenvolvimento Institucional de cada instituição de ensino credenciada para educação a distância (BRASIL, 2017).

Verificamos uma concatenação coesiva típica de textos legislativos não composta por anáforas nominais ou pronominais, senão constituída por 
dispositivos metatextuais e intratextuais com a retomada ou remissão nominal explícita de artigo, de parágrafo, de inciso em detrimento de verbos, de pronomes e de adjetivos na primeira e segunda pessoa do singular e plural. Nesse sentido, atestamos a presença mais acentuada de nomes comuns com valor exofórico no protagonismo das ações elencadas. Ademais, curiosamente identificamos a presença de frases passivas, em tese, mais prováveis no discurso teórico (excerto 7).

\section{Discurso teórico}

O discurso teórico é presentificado em menor proporção no documento analisado, contudo, ele se concretiza monologado e desprovido de frases declarativas em alguns segmentos textuais (excerto 3 e 22):

\section{Excerto 22}

Art. $5^{\circ}$ O polo de educação a distância é a unidade acadêmica e operacional descentralizada, no País ou no exterior, para o desenvolvimento de atividades presenciais relativas aos cursos ofertados na modalidade a distância.

Outros aspectos verificados nos segmentos em pauta caracterizadores do discurso teórico foram: a) caráter conjunto autônomo marcado com exploração do dos tempos verbais com dominância dos verbos no presente (presente) e ausência, no caso, de futuro; b) a ausência de unidades de remissão aos interactantes, ou ao espaço tempo da produção, os dêiticos espaciais e temporais, por exemplo; c) não presença de nomes próprios e de pronomes e adjetivos de primeira e segunda pessoa do singular com valor claramente exofórico e ausência de verbos na primeira e segunda pessoa do singular; densidade verbal muito fraca e densidade sintagmática elevada.

\section{Considerações Finais}

Consideramos, a partir da análise concretizada, que os segmentos textuais 
focalizados denotam uma escassa presença de sintagmas referentes aos professores ou profissionais mediadores da EaD. Ademais, quando presentes, esses sintagmas reportam-se a seres ou profissionais no papel de agentes, ou seja, desprovidos de motivos, capacidades e intenções (BRONCKART; MACHADO, 2004).

Nas reformuladas definições de EaD que vigoram nos Decretos, a remissão aos humanos se materializa, num caso de figuração do papel semântico "agentivo" e, noutro caso, no papel "atributivo". Assim sendo, ponderamos que o escopo analítico efetuado neste trabalho apresenta, especificamente, os papéis representados por agentes na definição de EaD. Logo, uma análise dos demais segmentos na perspectiva da Semiologia do Agir pode revelar outros papéis sintático-semânticos para além daqueles identificados aqui.

É evidente que, mesmo decorridos duas décadas do principal marco regulatório da $\mathrm{EaD}$ no Brasil, a sua regulamentação funda-se num ato normativo que, em sua natureza genérica volta-se, sobremaneira, para instâncias inanimadas evocadas.

Cabe observarmos que, nessa lacuna, ou em outros termos, nesse percurso estabelecido pela dinâmica do sistema jurídico no estado democrático de direito, delega-se ao coletivo de trabalho e aos profissionais da educação a oportunidade de exercerem seus efetivos papéis autorais no âmbito dos atos administrativos institucionais (regulamentos, projetos, programas educacionais, etc.) e autoprescrições (planejamentos de aula, notas de campo, dentre outros) numa perspectiva mais específica. Contudo, suprime-se esse espaço quando a prescrição parte de uma instância hierarquicamente superior.

Nesse sentido, dada necessidade de analisar também as prefigurações ascendentes, atentamo-nos para Bronckart e Machado (2004), Abreu Tardelli (2004), Fillietaz (2004) e Plazaola Giger (2004) que preconizam a necessidade de outros métodos e materiais escritos e orais que contemplem o entorno e a situação do agir para a elaboração mais precisa da imagem ou representação do trabalho educacional que se delineia, inevitavelmente, entre a norma e o estilo particular. 


\section{Referências}

ABREU TARDELLI, Lilia Santos. O trabalho do professor em EaD na lente da legislação. In: MACHADO, Anna Rachel (org.). O ensino como trabalho: uma abordagem discursiva. Londrina: EDUEL, 2004. p. 168-197.

BRASIL. Decreto no 2.494, de 10 de fevereiro de 1998. Regulamenta o Art. 80 da LDB (Lei n.o 9.394/96). Brasília, DF: Câmara dos Deputados, 1998.

Disponível em:

http://portal.mec.gov.br/seed/arquivos/pdf/tvescola/leis/D2494.pdf. Acesso em: 11 jun. 2018.

BRASIL. Decreto no 5.622, de 19 de dezembro de 2005. Regulamenta o art. 80 da Lei no 9.394, de 20 de dezembro de 1996, que estabelece as diretrizes e bases da educação nacional. Brasília, DF: Presidência da República, 2005. Disponível em: http://www.planalto.gov.br/ccivil_03/_ato20042006/2005/decreto/d5622.htm. Acesso em: 11 jun. 2018.

BRASIL. Decreto no 9.057, de 25 de maio de 2017. Regulamenta o art. 80 da Lei no 9.394, de 20 de dezembro de 1996, que estabelece as diretrizes e bases da educação nacional. Brasília, DF: Presidência da República, 2017. Disponível em: http://imprensanacional.gov.br/materia//asset_publisher/Kujrw0TZC2Mb/content/id/20238603/do1-2017-05-26-decreton-9-057-de-25-de-maio-de-2017-20238503. Acesso em: 2 jul. 2018.

BRASIL. Imprensa Nacional. Novas mídias. DOU adota compartilhamento nas redes sociais. Brasília, DF: Presidência da República, 2018a. Disponível em: http://portal.imprensanacional.gov.br/noticias-da-imprensa-nacional//asset_publisher/54vcxf9ztQ7x/content/id/32429631. Acesso em: 11 ago. 2018.

BRASIL. Lei no 9.394, de 20 de dezembro de 1996. Estabelece as diretrizes e bases da educação nacional. Brasília, DF: Presidência da República, 1996. Disponível em: http://www.planalto.gov.br/Ccivil_03/leis/L9394.htm. Acesso em: 5 jun. 2018.

BRASIL. Manual de redação da Presidência da República. 3. ed. Brasília: Presidência da República, 2018b. Disponível em:

http://www4. planalto.gov.br/centrodeestudos/assuntos/manual-de-redacao-dapresidencia-da-republica/manual-de-redacao.pdf. Acesso em: 11 ago. 2018.

BRONCKART, Jean-Paul. Atividade de linguagem, textos e discursos: por um sócio-interacionismo-discursivo. Tradução de Anna Rachel Machado e Péricles Cunha. São Paulo: EDUC, 2009.

BRONCKART, Jean-Paul. Um retorno necessário à questão do desenvolvimento. In: BUENO, Luzia; LOPES, Maria Ângela Paulinio Teixeira; CRISTOVÃO, Vera 
Lúcia Lopes (org.). Gêneros textuais e formação inicial: uma homenagem à Malu Matêncio. Campinas: Mercado de Letras, 2013. p. 85-109.

BRONCKART, Jean-Paul; MACHADO, Anna Rachel. Procedimentos de análise de textos sobre o trabalho educacional. In: MACHADO, Anna Rachel (org.). $O$ ensino como trabalho: uma abordagem discursiva. Londrina: EDUEL, 2004. p. 131-163.

BUENO, Luzia; TRAVA, Sandra Memari. O professor e seu papel no manual do PNAIC. In: NASCIMENTO, Elvira Lopes; ROJO, Roxane Helena Rodrigues (org.). Gêneros de texto/discurso e os desafios da contemporaneidade. 2. ed. Campinas, SP: Pontes Editores, 2016. p. 191-207.

DI PIETRO, Maria Sylvia Zanella. Direito administrativo. São Paulo: Atlas, 2011.

DOLZ, Joaquim; SCHNEUWLY, Bernard; NOVERRAZ, Michèle. Seqüências didáticas para o oral e a escrita: apresentação de um procedimento. In: SCHNEUWLY, B.; DOLZ, J. Gêneros orais e escritos na escola. Campinas, SP: Mercado de Letras, 2004. p. 95-128.

FILLIETTAZ, Laurent. As contribuições de uma abordagem praxeológica do discurso para a análise do trabalho do professor: o enquadramento das atividades em aula. In: MACHADO, Anna Rachel (org.). O ensino como trabalho: uma abordagem discursiva. Londrina: EDUEL, 2004. p. 199-235.

GOMES, Luiz Fernando. EAD no Brasil: perspectivas e desafios. Avaliação, Campinas, v. 18, n. 1, p. 13-22, 2013. Disponível em:

http://submission.scielo.br/index.php/aval/article/view/113548/8001. Acesso em: 17 jul. 2018.

INSTITUTO NACIONAL DE ESTUDOS E PESQUISAS EDUCACIONAIS ANÍSIO TEIXEIRA. Sinopse estatística da educação superior 2016. Brasília: Inep, 2017. Disponível em: http://portal.inep.gov.br/basica-censo-escolar-sinopse-sinopse. Acesso em: 10 ago. 2018.

MACHADO, Anna Rachel; LOUSADA, Eliane; BARALDI, Glaucimara; ABREUTARDELLI, Lília Santos; TOGNATO, Maria Izabel Rodrigues. Relações entre linguagem e trabalho educacional: novas perspectivas e métodos no quadro do interacionismo sociodiscursivo. Calidoscópio, São Leopoldo, RS, v. 2, n. 2, p. 89-96, jul./dez. 2004.

NOUROUDINE, Abdallah. A linguagem: dispositivo revelador da complexidade do trabalho. In: SOUZA-E-SILVA, Maria Cecília; FAÏTA, Daniel (org.). Linguagem e trabalho: construção de objetos de análise no Brasil e na França. Tradução de Ines Polegatto e Décio Rocha. São Paulo: Cortez, 2002.

PLAZAOLA GIGER, Itziar. O discurso do professor sobre sua própria ação: In: MACHADO, Anna Rachel (org.). O ensino como trabalho: uma abordagem 
discursiva. Londrina: EDUEL, 2004. p. 237-270.

ZAMLUTTI, Maria Esmeralda Mineu. Uma análise do surgimento da educação a distância no contexto sociopolítico brasileiro do final da década de 30 e início da década de 40. 2006. Tese (Doutorado em Educação) - Universidade Estadual de Campinas, Campinas, 2006. 